\begin{tabular}{cc}
$\begin{array}{c}\text { Yanbu Journal } \\
\text { of } \\
\text { Engineering } \\
\text { and Science }\end{array}$ & Vol. 7, October $2013(1434 \mathrm{H})$ \\
\hline \hline ISSN: $1658-5321$ & www.yjes.org.sa
\end{tabular}

\title{
MAXIMUM SHEAR STRESS ANALYSIS OF SPUR GEAR STRENGTH
}

\author{
Salah Gasim Ahmed \\ Department of Mechanical Technology, Yanbu Industrial College, \\ P.O. Box 30436, Yanbu Al-Sinaiyah, Kingdom of Saudi Arabia \\ E-mail: smohammed@yic.edu.sa. \\ *On leave from Faculty of engineering, University of Karary, Sudan
}

\begin{abstract}
Gears are commonly used for transmitting power between shafts, which imposes the need for higher endurance and reliability, this can be achieved only with the aid of clear and precise knowledge of the stresses on gear tooth during operation. This paper investigates the stresses at gear tooth at both tension and compression sides of the tooth. The analysis of the tooth strength in this paper is based on the maximum shear stress theory. A new equation similar to Lewis's equation was obtained but with a different form factor. The new derived equation is compared to the respective Lewis's known equation. It was found that Lewis's equation is not conservative as thought before. It is only as good as the new equation when applied to the tension side. But on the compression side it is not adequate.
\end{abstract}

Keywords: Spur Gears, Maximum Shear Stress Theory, Lewis's Equation, Form Factor.

\section{INTRODUCTION}

Gears are common mechanical parts in many machines. A lot of attention and research works have been devoted to improve the design and manufacturing of gears.

The design of spur gears is based mainly on the strength of the teeth and the contact stress on tooth surface, $[1,2,3]$. Other factor such as shocks, size effects, and uneven load distribution are also introduced to improve the spur gear design [4], [5].

The load acting on a single pair of spur gear is shown in figure (1). The force, $\left(\mathrm{F}_{\mathrm{n}}\right)$, transmitted from the driver to the driven gear is usually normal to the contact surfaces and is inclined to the common tangent, of the two gears, by an angle $\phi$, which is called the pressure angle.
This force can be analysed into two components:

Tangential force, $F_{t}=F_{n} \times \cos \phi$

Radial force, $\quad F_{r}=F_{n} \times \sin \phi$

$F_{r}=F_{t} \times \tan \phi$

$\phi$ : pressure angle

These are the relevant forces when considering gear teeth strength.

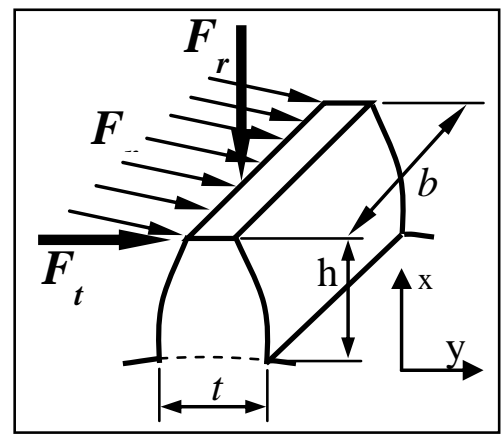

Fig.1. The acting load on a single point of spur gear 


\section{LEWIS EQUATION FOR GEAR STRENGTH}

Historically, Lewis is the first who developed an equation to estimate the gear teeth strength. The equation is based on stress resulting from the tangential component $\left(F_{t}\right)$ only. The radial component $\left(\mathrm{F}_{\mathrm{r}}\right)$ is ignored totally. The tooth is treated as cantilever with contact taking place at the tip as shown in figure (1). The tangential component $\left(F_{t}\right)$, only, is considered in the analysis, see figure (1). In this analysis only one pair of teeth is assumed to be in contact at any time. The effect of the fillet, at the tooth root, on the stress concentration is ignored. For the cantilever formed tooth, the maximum stress is found at the tooth root. The application of the standard bending stress equation $(S=M / Z)$ leads to:

$$
S=\frac{6 F_{t} h}{b t^{2}}
$$

Where,

$$
\begin{aligned}
& \mathrm{S}=\text { bending stress in gear tooth } \\
& \mathrm{F}_{\mathrm{t}}=\text { tangential tooth load } \\
& \mathrm{b}=\text { face width of tooth } \\
& \mathrm{h}=\text { tooth depth } \\
& \mathrm{t}=\text { tooth thickness }
\end{aligned}
$$

The normal force is assumed to be uniformly distributed along the face width.

The factor $t^{2} / 6 h$ is a geometrical property of the size and shape of the tooth. It may, therefore, be expressed as a function of the circular pitch $\mathrm{p}_{\mathrm{c}}$ by the relation:

$\frac{t^{2}}{6 h}=y p_{c}$

Where $\mathrm{y}$ is an abstract number known as Lewis form factor.

Using the diamteral pitch instead of the circular pitch, the form factor is denoted by $\mathrm{Y}$,
$(\mathrm{Y}=\pi \mathrm{y})$, the factor $\mathrm{Y}$ is also called the form factor.

Also $t^{2}=6 h y p_{c}=\frac{6 h Y p_{c}}{\pi}=\frac{6 h Y}{P_{d}}$

Substituting equation (4) into equation (2) we obtain:

$S_{b}=\frac{F_{t} P_{d}}{b Y}$

The Lewis form factor depends on both the number of teeth $\mathrm{N}$ and the pressure angle $\phi$. It is available in a form of a chart or a table.

\section{AGMA GEAR STRESS EQUATION}

AGMA equation is based on modified Lewis equation and it takes into account:

1. Stress concentrations at the tooth root

2. The effects of multiple pairs of teeth in contact $\sigma=W_{t} P K_{v} K_{o} K_{m} K_{s} K_{B} / F J$

gear geometry factor $(\mathrm{J})$

velocity factor $\left(\mathrm{K}_{\mathrm{v}}\right)$

overload factor $\left(\mathrm{K}_{\mathrm{O}}\right)$

mounting factor $(\mathrm{Km})$

size factor $(\mathrm{Ks})$

rim thickness factor $\left(\mathrm{K}_{\mathrm{B}}\right)$

Bearing in mind that, the AGMA geometry factor $J$ is based on the numbers of teeth of both mating gears.

Many techniques have been used to improve the design of gears. Figure (2) shows the analysis of two gear teeth in contact using photo-elasticity technique. Two types of high stress are shown on the teeth. As a result of bending a tensile stress is generated at $\mathrm{A}$ and a compressive stress at B. The inward component of the tooth force $\left(F_{r}\right)$ increases the compressive stress at B. The cyclic bending stress occurs once per revolution of the gear. It will lead to a fatigue failure.[7] At point $\mathrm{C}$, rolling and slide of two surfaces, will develop a contact stress situation which may results into a surface fatigue of the tooth. 


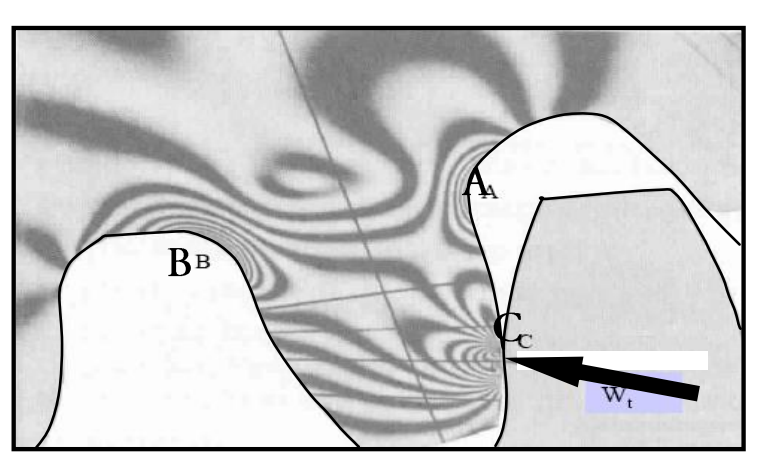

Fig.2. Photo-elastic analysis of spur gear teeth

With complicated geometry the stress of an elastic body, can be obtained by applying the FEM. There have been abundant research studies in this area $[6,7,8]$

Wei investigated the characteristics of an involute gear system. He considered bending stresses, contact stresses, and transmission errors of gears during meshing. [8]

Raptis et al carried a comparison between the results of photo-elasticity experiments, This technique is the widely applied method for gear stress analysis, together with the results of the FEM obtained by ANSYS software. They reached a conclusion that the deviations between the two applied methods are acceptable. This because of the possible errors that may occur during the implemetation of the two methods. [4]

Sankar et al examined the effect of stress concentration on the tooth failure in spur gears at the tooth root. In order to avoid tooth damage they introduced corrective measures, mainly introducing profile modification in root fillet. A circular root fillet instead of the standard trochoidal root fillet is introduced in spur gear and analyzed using ANSYS software. [9]

Hassan [2], studied the surface failure resulting from repetitions of the contact stress, by applying finite element method. A special technique was used in order to distinguish between the contact regions, The contact region is divided into two bodies: target region and the contact region. Target elements were used for target region, while contact elements were used in contact region. He reported that , both stress results, obtained from AGMA calculation method and that obtained by the method he applied are practically identical.

This work applies one of the theories of failure, mainly maximum shear stress because it is simple and for ductile materials it gives reasonably good results.

\section{MAXIMUM SHEAR STRESS ANALYSIS}

Considering the effect of the normal force acting on a single tooth there are three important stresses will be given more attention in this analysis. Other stresses like contact stresses will be ignored as the analysis is only concerned about the stresses at the gear tooth root.

The main stresses acting at the root are:

1.Bending stress $\left(S_{b}\right)$ resulting from the tangential force $\mathrm{F}_{\mathrm{t}}$

2.Compressive stress $\left(S_{c}\right)$ resulting from the radial force $\mathrm{F}_{\mathrm{r}}$

3.Shear Stress $\left(\mathrm{S}_{\mathrm{s}}\right)$ resulting from the tangential force $F_{t}$

The bending stress is as shown by equation (5), Lewis's modified equation:

$S_{b}=\frac{F_{t} P_{d}}{b Y}$

The compressive stress due to the radial load, $\mathrm{F}_{\mathrm{r}}$ can be shown equal to:

$S_{c}=\frac{F_{r}}{b t}$
$S_{c}=\frac{F_{t} \times \tan \phi}{b t}=\frac{F_{t} \tan \phi}{b \sqrt{\frac{6 h Y}{P_{d}}}}$

But the tooth depth, $\mathrm{h}=\frac{2.157}{P_{d}}$ 


$$
\begin{aligned}
& S_{c}=\frac{F_{t} \tan \phi}{b \sqrt{\frac{6 \times 2.157 \times Y}{P_{d} \times P_{d}}}} \\
& S_{c}=\frac{0.28 \times F_{t} \tan \phi \times P_{d}}{b Y^{0.5}} \\
& S_{c}=0.28 \frac{F_{t} P_{d}}{b Y} Y^{0.5} \tan \phi
\end{aligned}
$$

The total axial stress:

$$
\begin{aligned}
& S_{x}=S_{b} \pm S_{c} \\
& S_{x}=\frac{F_{t} P_{d}}{b Y}\left(1 \pm 0.28 Y^{0.5} \tan \phi\right)
\end{aligned}
$$

Similarly the shear stress due to the tangential load $F_{t}$ can be shown equal to

$$
\begin{aligned}
& S_{s}=\frac{F_{t}}{b h} \\
& S_{s}=0.28 \frac{F_{t} P_{d}}{b Y} Y^{0.5}
\end{aligned}
$$

The maximum shear theory, of Guest, assumes that the elastic limit of a material is reached when the greatest resultant shear stress reaches a certain limit as determined under the condition of pure shear. According to this theory a member subjected to tensile stress fails when the maximum shear stress exceeds $1 / 2 S_{e}$, where $S_{e}$ is the elastic limit in tension.[10] In the case of combined load the member will fail when its maximum shear stress exceeds the elastic limit in shear, in other words:

Max. Shear stress $=\frac{1}{2} \sqrt{\left(S_{x}-S_{y}\right)^{2}+4 S_{s}^{2}}=\frac{1}{2} S_{e}$

$$
\begin{aligned}
& S_{\max }=\frac{1}{2} \sqrt{\left(\frac{F_{t} P_{d}}{b Y}\right)^{2}\left(1 \pm 0.28 Y^{0.5} \tan \phi\right)^{2}+4\left(\frac{F_{t} P_{d}}{b Y}\right)^{2}\left(0.28 Y^{0.5}\right)^{2}} \\
& S_{s}=\left(\frac{F_{t} P_{d}}{2 b Y}\right) \sqrt{\left(1 \pm 0.28 Y^{0.5} \tan \phi\right)^{2}+4\left(0.28 Y^{0.5}\right)^{2}} \\
& S_{s}=\left(\frac{F_{t} P_{d}}{2 b Y}\right) \sqrt{1 \pm 2 \times 0.28 Y^{0.5} \tan \phi+\left(0.28 Y^{0.5} \tan \phi\right)^{2}+4\left(0.28 Y^{0.5}\right)^{2}}
\end{aligned}
$$

For a pressure angle of $20^{\circ}, \tan \phi=0.364$

$S_{s}=\left(\frac{F_{t} P_{d}}{2 b Y}\right) \sqrt{1 \pm 2 \times 0.28 Y^{0.5} \times 0.364+\left(0.28 Y^{0.5} \times 0.364\right)^{2}+4\left(0.28 Y^{0.5}\right)^{2}}$

$$
\begin{aligned}
& S_{s}=\left(\frac{F_{t} P_{d}}{2 b Y}\right) \sqrt{1 \pm 0.2 Y^{0.5}+0.01 Y+0.31 Y} \\
& S_{s}=\left(\frac{F_{t} P_{d}}{2 b Y}\right) \sqrt{1 \pm 0.2 Y^{0.5}+0.32 Y}
\end{aligned}
$$

Shear stress for most materials $S_{s}=0.5 x S_{e}$

$$
\begin{aligned}
0.5 S_{\mathrm{e}}=\left(\frac{F_{t} P_{d}}{2 b Y}\right) \sqrt{1 \pm 0.2 Y^{0.5}+0.32 Y} \\
F_{t}=\frac{0.5 \times 2 \times S_{e} \times b \times Y}{P_{d} \sqrt{1 \pm 0.2 Y^{0.5}+0.32 Y}} \\
F_{t}=\frac{S_{e} \times b \times Y}{P_{d} \sqrt{1 \pm 0.2 Y^{0.5}+0.32 Y}} \\
F_{t}=\frac{S_{e} b}{P_{d}} \frac{Y}{\sqrt{1 \pm 0.2 Y^{0.5}+0.32 Y}}
\end{aligned}
$$

The factor $Y_{\mathrm{n}}=\frac{Y}{\sqrt{1 \pm 0.2 Y^{0.5}+0.32 Y}}$ is the new form factor taking into account the effect of the combined stresses and applying the maximum shear stress theory.

\section{CONCLUSION}

Figure (3) shows the plot of Lewis's and the maximum shear stress form factor.

The maximum shear stress form factor is plot for both tension and compression sides of the gear tooth.

The new form factor for the tension side coincides almost exactly with Lewis's form factor. This indicates that Lewis's equation is not conservative as it was believed when considering maximum shear stress. On the other hand the compression side has lower form factor.

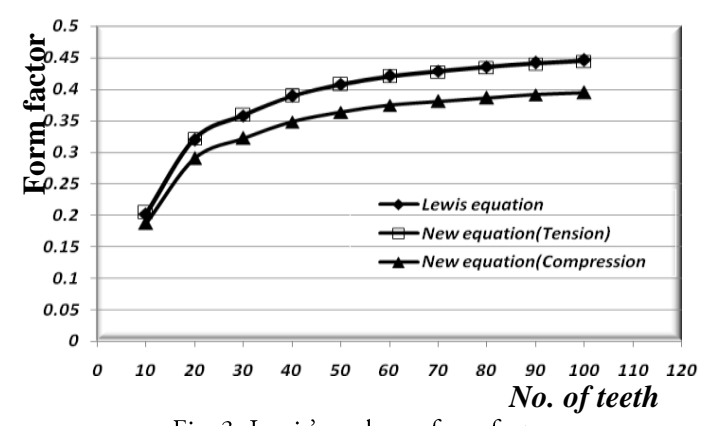

Fig. 3. Lewis's and new form factors 
Higher form factor indicates that the tooth is capable of transmitting higher force. But failure usually occurs on the tension side.

Gear-tooth failure due to bending fatigue generally is the outcome of the crack originating in the root of the tooth, see figure (4). As a result of fatigue the whole tooth or part of it, fractures away. Most often there is evidence of a fatigue "eye" or focal point of the break. The break shows signs of fretting and conventional smooth beach marks in the break area. Generally there is small area that shows rough, jagged appearance, indicating this was the last portion of the tooth to break away.

TABLE 1: COMPARISON BETWEEN LEWIS'S EQUATION AND MAXIMUM SHEAR STRESS EQUATION

\begin{tabular}{|c|c|c|c|}
\hline $\begin{array}{c}\text { No. of } \\
\text { Teeth }\end{array}$ & $\mathrm{Y}$ & $\mathrm{Y}_{\mathrm{nt}}$ (Tension) & $\begin{array}{c}\mathrm{Y}_{\mathrm{nc}} \\
\text { (Compression) }\end{array}$ \\
\hline 10 & 0.201 & 0.204 & 0.187 \\
\hline 20 & 0.32 & 0.322 & 0.290 \\
\hline 30 & 0.358 & 0.359 & 0.322 \\
\hline 40 & 0.389 & 0.389 & 0.348 \\
\hline 50 & 0.408 & 0.407 & 0.364 \\
\hline 60 & 0.421 & 0.420 & 0.374 \\
\hline 70 & 0.429 & 0.428 & 0.381 \\
\hline 80 & 0.436 & 0.434 & 0.387 \\
\hline 90 & 0.442 & 0.440 & 0.392 \\
\hline 100 & 0.446 & 0.444 & 0.395 \\
\hline
\end{tabular}

\section{REFERENCES}

[1] Refaat M. H. and Meguid S. A., on the contact stress analysis of spur gears using variational inequalities, Computers and structures, Vol. 57, No.5, pp. 871-882, 1995

[2] Dr. Ali Raad Hassan, Contact Stress Analysis of Spur Gear Teeth Pair, World Academy of Science, Engineering and Technology 58 page 611-616, 2009
[3] Johnson K.L., 'Contact Mechanics', Press Syndicate of the University of Cambridge, London, New York, Melbourne, 1985

[4] Shigley J. E. et.al, Mechanical Engineering Design, McGraw Hill: $7^{\text {th }}$ edition, 2004.

[5] Maleev and Hartman's, Machine design, CBS Publishers \& Distributors, ISBN 81-239-0637-4, 2004

[6] KG. Raptis, TN. Costopoulos, G. A Papadopoulos and A D. Tsolakis, Rating of Spur Gear Strength Using Photoelasticity and the Finite Element Method, American J. of Engineering and Applied Sciences 3 (1): 222-231, 2010

[7] Klenz, S. R., "Finite Element of A Spur Gear Set”, M.Sc. Thesis, Dept. of Mechanical Engineering, University of Saskatchewan, 1999

[8] Zeping Wei, Stresses and Deformations in Involutes Spur Gears by Finite Element Method, Thesis, College of Graduate Studies and Research, University of Saskatchewan, Canada, 2004

[9] S Sankar, MS Raj, M Nataraj, Profile Modification for Increasing the Tooth Strength in Spur Gear Using CAD, Engineering, 2, 740749, 2010

[10] Shigley J E, Mischke C R, and Budynas R G, Mechanical Engineering Design, ISBN 007252036-1, $7^{\text {th }}$ edition McGraw Hill, Higher Education, 2004 


\title{
تحليل الاجهادات على التروس المهمازية بتطبيق نظرية أقصى اجهاد قص
}$$
\text { صلاح قاسم أحمد }
$$$$
\text { قسم تقنية الهندسة الميكانيكيةــ كلية ينبع الصناعية }
$$

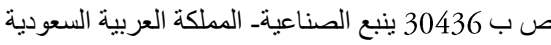

| (لملخص:

تستعمل التروس، العجلات المسننة، عادةً لنقل القدرة بين الأعمدة و هذا يحتاج لقدرة تحمل و اعتمادية عالية. ويمكن التوصل لذلك بمعرفة دقيقة للاجهادات التي تؤثر على التروس. هذا البحث يتتاول الاجهادات التي تؤثر على اسنان التروس في جانبى السنة. يعتمد تحليل الاجهاد في هذا البحث على نظرية أقصى اجهاد قص. نم التوصل إلى معادلة مشابهة لمعادلة لوبس الشائعة و لكن بمعامل شكل جديد.

مقارنة المعادلة الجديدة بمعادلة لويس أوضحت أن معادلة لويس ليست محافظة كما كان بعتقد. بل تطبيقها علي الجانب الذي بتعرض لاجهادات ضغط يبين أن معادلة لويس غير مناسبة. 